\title{
Investigating the Zen concept in the interior setting to engage customer place attachment: An interior design for a Japanese restaurant in Bandung
}

D. Murdowo \& S.M. Lazaref

Telkom University, Bandung, Indonesia

\begin{abstract}
This study investigates how a Japanese restaurant incorporates the attributes of Japanese culture and the Zen concept in its interior setting to engage customer place attachment. The research used a qualitative method with a case study at the Shabu Kojo restaurant in Bandung. Qualitative research was performed by conducting interviews and distributing questionnaires to customers. To implement the research, the Zen concept was applied in the form of natural colors, shapes, artificial lighting, and traditional furniture with Kanji letters, as well as comfortable rooms for gathering. The research demonstrated that the principles of the Zen concept, style of Japanese culture, and Japanese philosophy can be used to produce interior design and engage customer attachment. These research findings will be a reference for to enrich further research.
\end{abstract}

Keywords: interior setting, customer place attachment, Zen concept, Japanese restaurant

\section{INTRODUCTION}

Most customers visiting ethnic restaurants expect to engage in place attachment and experience the authentic atmosphere of the restaurant's origin. The phenomenon of place attachment is one potentially important characteristic of satisfied and loyal customers (Rojak \& Cole 2015). One aspect that supports place attachmen is its interior design. As has been stated by Andreani et al. (2013), the unique and ancient interior and exterior design of a restaurant can easily attract consumers. In fact, a restaurant's interior design is one of the essential factors that helps make a restaurant a destination (Rahma et al. 2017). Meanwhile, Levy \& Weitz (2001) state that adequate interior design creates a feeling of comfort, pleasure, relaxation, and calm that creates a feeling of satisfaction from the customer. The Shabu Kojo restaurant is a typical Japanese traditionalstyle restaurant designed to connect it to Japanese culture via its interior design. Some traditional Japanese ambiance applications are used such as in lighting, furniture, and atmosphere.

Based on the observations conducted through customer interviews and questionnaires at the Shabu Kojo restaurant, a restaurant's interior design aspects that best represent Japanese culture and philosophy are its atmosphere, colors, natural materials, lighting and ambience, furniture, and comfortable private rooms. However, the Shabu Kojo restaurant has not applied all those representations. Therefore, there is a need to create an interior design that will engage customer place attachment. This study investigated the restaurant's visitor experience and comfort perceptions and then demonstrated how to apply the Zen concept in a Japanese restaurant.

The Zen concept as a Japanese cultural principle is well known among Indonesians. The Zen concept is a classic trend that brings a sense of peace and balance. The principle in Zen interior is to balance the arrangement of life and the rooms, life in the room and the room itself are two things that affect each other (Ashralika 2019). Wirayuda (2020) explains that the Zen concept can be applied to in the following ways: (1) color selection; (2) shapes; (3) lighting and ambience; 


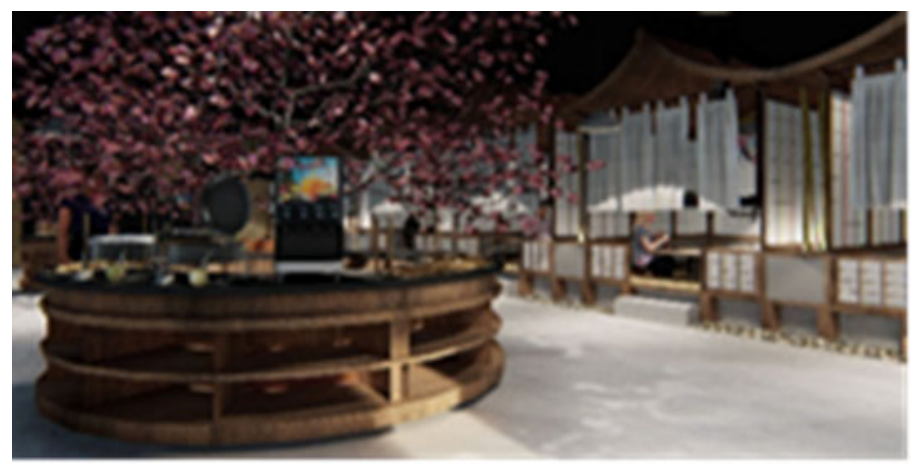

Figure 1. Color application. (Source: Personal Documentation, 2020).

(4) furniture; and (5) comfortable private rooms. Therefore, there is a need to improve Sabu Kojo restaurant's aesthetics and functionality so as to be strongly identified as a Japanese restaurant.

\section{RESEARCH METHODS}

The research uses a qualitative method with a case study from the Sabu Kojo restaurant in Bandung. The restaurant was chosen as the research object because it is one of the local Japanese restaurants with a definite connection to Japanese culture.

The research started from data observation and data collection by interviewing 4 customers and distributing 20 questionnaires. The interviews and questionnaires explored how the existing interior represented Japanese culture, as well as questions about the overall interior and expectations of what interior could be. The next step was analyzing what concept was relevant to customer expectation. The final step was to design the interior.

\section{RESULTS AND DISCUSSION}

\subsection{Theme and concept design}

The Zen concept is a classic trend that can bring a sense of peace and balance. The theme design of this Japanese restaurant was "beauty is the harmony of purpose and style" and the atmosphere created by the interior was comfortable, warm, friendly, and homey.

\subsection{Color application}

Zen is the path to enlightenment and its design theory is based on light. The theory of color psychology mentions that brown is identical to something natural. These colors have the power to create relaxation and calm. The colors expressed by light are the calmest and most harmonious when the colors are natural like sunlight (Ashralika 2019). Darker colors evoke different moods and can be preferred in different dining situations, leading to different colors choices for tableware (Bao et al. 2018). When the color white is used properly, it is an effect that will not disappoint. The use of natural colors is the hallmark of the Zen concept, as seen in Figure 1.

\subsection{Architectural shape}

The application of interior shapes such as rectangles to the design theme brings in the feeling of natural resources which correlates to the principle of Japanese life that it is important to always 

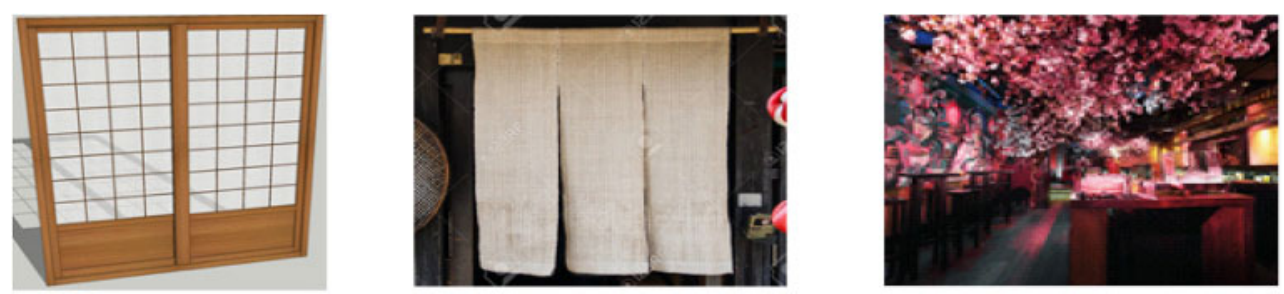

Figure 2. Implementation of natural resources. (Source: www.google.com).
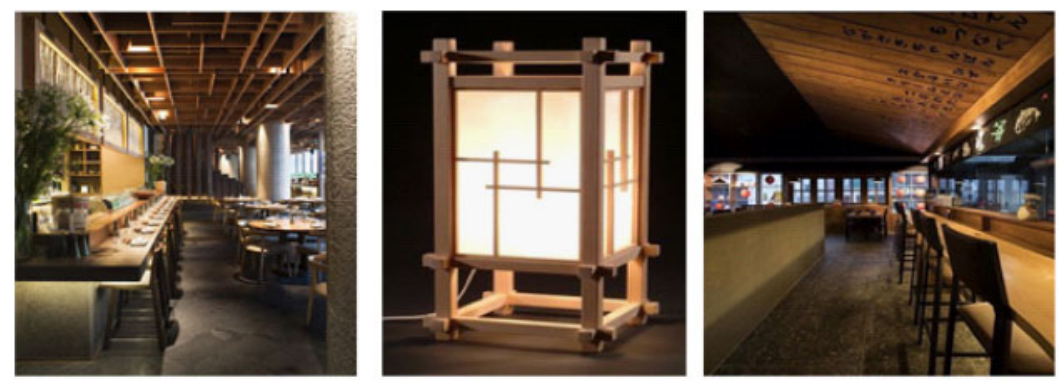

Figure 3. Lighting application (Source: www.pinterest.com).

being close to nature (Widjaja 2013) and in harmony with nature (Inayah 2017). The restaurant wall is designed to resemble the shape of a traditional Japanese house to give the impression of being in a Japanese environment (Figure 2), further enhanced with aesthetic elements such as paintings, ornaments, and lanterns that adorn other dining areas. In addition to massive walls, temporary walls are used in the stretch area to maintain privacy between customers. The partition that would use shoji is a panel made of a wooden frame and transparent paper, with the addition of a curtain cloth to better maintain customer privacy.

\subsection{Lighting}

The implementation of lighting in restaurant can be divided into two categories: natural and artificial (Figure 3). Natural lighting is optimized through relatively large glass windows with Japanese patterned shading. Artificial lighting uses general lighting and accent lighting used in the form of hanging lamps, downlights, and track lamps. Hanging lamps are used in the circulation and dining areas, as general lighting and accent lighting use lanterns installed in each bulkhead between the tatami dining areas. Chandelier lights are used in the buffet area. The lighting is bright to accommodate cooking and eating activities, but the outside dining area is relatively dimmer by only using hidden lights on the floor area for direction, in addition to a hanging lamp that further lights the way.

\subsection{Furniture}

The furniture concept based on the Zen style is designed with simple characteristics and natural materials. The main furniture application concept is used in the form of a dining table and tatami made of wood and bamboo, serving as a dining area. Other supporting accessories used in restaurants are Japanese decorative accessories, such as typical Japanese paintings and Japanese patterns. According to Rucitra \& Permatasari (2017), chair furniture is designed according to function, while still paying attention to elements of Japanese culture such as the shape of the Kanji letters and the application of Kanji in the form of chair furniture designs (Figure 4). 


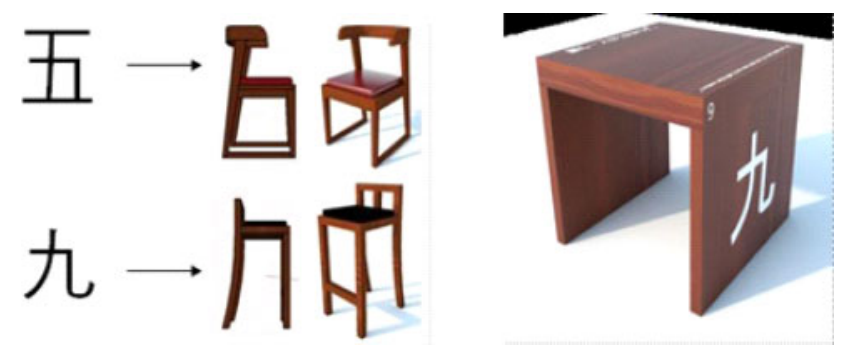

Figure 4. Kanji letters in furniture application (Source: Personal Documentation 2017).
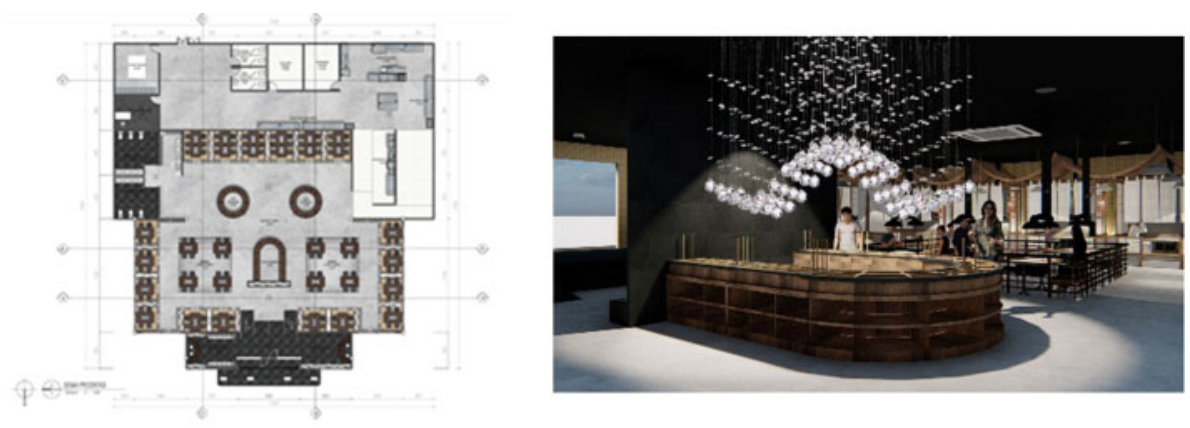

Figure 5. Buffet area visualization. (Source: Personal Documentation 2020).

\subsection{Space classification and a comfortable room}

Customer expectations of a comfortable room can be designed with two dining areas, namely a public dining area that has a four-seat tatami dining area and a six-seat tatami dining area. The classification of the space is based on the needs and activities that occur in the restaurant during the activity.

Figure 5 showcases the design of the buffet area. The center of visitor activities takes place inside the restaurant so this area is in the middle making easier to access for visitors. The application of wood on the buffet table and natural stone on the walls creates a natural atmosphere that increases the comfort of visitors.

\section{CONCLUSION}

This study examined the Sabu Kojo restaurant, a Japanese restaurant in Bandung. The restaurant's Japanese design style has a theme of "beauty is the harmony of purpose and style."

The application of the Zen concept is represented by calm and harmonious colors. Architectural shapes such as rectangles are designed for using natural materials such as exposed concrete flooring, tatami, and granite that are applied in paintings, ornaments, and dining area. Natural lighting is applied through large glass windows with Japanese patterned shading, meanwhile artificial lighting is used in the form of hanging lamps, downlights, and track lamps. The furniture concepts applied in the dining table and tatami are made of wood and bamboo in the shape of the Kanji letters. The comfortable room is designed as a public dining area that features a large sitting table in the middle of the room at which one can relax and be comfortable together.

The Zen concept can meet customer place attachment which can enrich the customer experience. This research can be used a reference for other ethnic restaurants. 


\section{REFERENCES}

Andreani, F., Kristanti, M., and Yapola, A. 2013. Pengaruh Store Layout, Interior Display, Human Variable Terhadap Customer Shopping Orientation di Restoran Dewandaru Surabaya. Jurnal Manajemen dan Kewirausahaan, 15(1), 65-74.

Ashralika, P. A. 2019. Menyeimbangkan Hidup \& Mendapatkan Suasana Menenangkan dengan Zen Interior Design. Retrieved from interiordesign.id: https://interiordesign.id/menyeimbangkan-hidup-zen-interiordesign/.

Suomiya Bao, Yusuke Shokawa, Satoshi Suzuki, and Toshimasa Yamanaka. 2018. Exploring the Role of Color in Dining Experience: Preference and Relationship between Tableware Color and Dining Scenes in Japanese Young Females. International Journal of Affective Engineering, 17(1), 19-26.

Inayah, N. H. 2017. Gaya Desain Zen, Ciptakan Suasana Ruang dengan Keseimbangan dan Keselarasan yang Sempurna. Retrieved from interiordesign.id: https://interiordesign.id/gaya-desain-zen/

Levy, M. and Weitz, B. 2001. Retailing Management, 4th Edition. New York: McGraw Hill Irwin.

Rahma, Miranti Sari, Prabu Wardono, and Lies Neni Budiarti. 2017. Pengaruh Elemen Interior Restoran terhadap Pengalaman Nostalgia Konsumen. Journal of Visual Art \& Desain Institut Teknologi Bandung, 9(2), 67-86.

Rojak, D. and Cole, L.B. 2015. Place Attachment and the Historic Brewpub: A Case Study in Greensboro, North Carolina. Journal of Interior Design 41(1), 33-50.

Rucitra, A. R. and Permatasar, R. A. L. 2017. Dekorasi Gaya Jepang dalam Desain Interior. Jurnal Dimensi Interior, 15(1), 56-61.

Widjaja, E. 2013. Studi Terapan Gaya Desain Interior Jepang Restoran Tomoto, Imari, Kayu, Nishiki Surabaya. Jurnal INTRA, 1(1), 1-10.

Wirayuda, Wisesa. (2020). 7 Alasan Mengapa Desain Gaya Zen Patut Dipilih untuk Hunian. Retrieved from: https://narasidesign.com/7-alasan-mengapa-desain-gaya-zen-patut-dipilih-untuk-hunian/. 